Article

\title{
Synthesis of 4-Arylselanyl-1H-1,2,3-triazoles from Selenium-Containing Carbinols
}

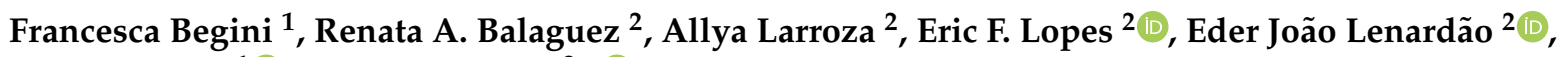 \\ Claudio Santi ${ }^{1}\left[\right.$ and Diego Alves ${ }^{2, *}$ (i) \\ 1 Group of Catalysis, Synthesis and Organic Green Chemistry, Department of Pharmaceutical Sciences \\ University of Perugia Via del Liceo 1, 06123 Perugia, Italy; francescabegini@hotmail.it (F.B.); \\ claudio.santi@unipg.it (C.S.) \\ 2 LASOL-CCQFA, Universidade Federal de Pelotas-UFPel, P.O. Box 354, 96010-900 Pelotas, Brazil; \\ renata.balaguez@gmail.com (R.A.B.); allya.larroza@gmail.com (A.L.); eric.francislopes@gmail.com (E.F.L.); \\ lenardao@ufpel.edu.br (E.J.L.) \\ * Correspondence: diego.alves@ufpel.edu.br; Tel.: +55-53-32757533
}

check for updates

Citation: Begini, F.; Balaguez, R.A.; Larroza, A.; Lopes, E.F.; Lenardão, E.J.; Santi, C.; Alves, D. Synthesis of 4-Arylselanyl-1H-1,2,3-triazoles from Selenium-Containing Carbinols. Molecules 2021, 26, 2224. https:// doi.org/10.3390/molecules26082224

Academic Editor: Georg Manolikakes

Received: 25 March 2021

Accepted: 9 April 2021

Published: 12 April 2021

Publisher's Note: MDPI stays neutral with regard to jurisdictional claims in published maps and institutional affiliations.

Copyright: (C) 2021 by the authors. Licensee MDPI, Basel, Switzerland. This article is an open access article distributed under the terms and conditions of the Creative Commons Attribution (CC BY) license (https:/ / creativecommons.org/licenses/by/ $4.0 /)$.

\begin{abstract}
In this work, we present a simple way to achieve 4-arylselanyl-1H-1,2,3-triazoles from selenium-containing carbinols in a one-pot strategy. The selenium-containing carbinols were used as starting materials to produce a range of selanyl-triazoles in moderate to good yields, including a quinoline and Zidovudine derivatives. One-pot protocols are crucial to the current concerns about waste production and solvent consumption, avoiding the isolation and purification steps of the reactive terminal selanylalkynes. We could also isolate an interesting and unprecedented by-product with one alkynylselenium moiety connected to the triazole.
\end{abstract}

Keywords: selenium; 1,2,3-triazoles; click chemistry; cycloaddition; carbinols; heterocycles

\section{Introduction}

Triazoles are a significant class of heterocycles which have received considerable attention because of their application in materials science, medicinal chemistry and organic synthesis [1-3]. Particularly, 1,2,3-triazoles derivatives exhibit a broad spectrum of biological properties, such as anti-inflammatory, antifungal, antibacterial, anticancer, antivirus and antituberculosis [4-13]. 1,2,3-Triazoles derivatives are an important connecting group, linking a broad range of substituted substrates in a simple fashion, being used as peptide mimetics [14,15]. Inspired in the Huisgen [3 +2] cycloaddition reaction of an organic azide and a terminal alkyne [16], a number of catalytic strategies employing transition metals have been used to address the reactivity and selectivity issues inherent to the seminal strategy [17-26]. In addition, recent studies have been directed toward the development of metal-free methodologies for triazole synthesis. Organocatalytic approaches involving [3 + 2] cycloaddition have been reported for the synthesis of functionalized 1,2,3-triazoles [27-34].

Despite the significant advances toward the synthesis of highly substituted 1,2,3triazoles, the need of a deep study on the combinations of substrates for the synthesis of highly functionalized and complex structures is still an open issue. In this sense, organoselanyl-triazoles constitute an interesting class of molecules, which combine the importance of a triazole nucleus [1-3] with an organoselenium moiety [35-38]. Selenium is an essential nutrient for mammals, playing important roles in metabolic pathways [39,40], and the interest in selenium pharmacology [41-46] and chemistry [47-49] has increased in this century.

Several methodologies have been reported for the selective synthesis of a range of 1,2,3-triazole scaffolds containing an organoselenium moiety [50-52]. However, only a few procedures to directly prepare 5-arylselanyl- and 4-arylselanyl-1H-1,2,3-triazoles have been 
described (Figure 1). For example, Cui et al. developed a simple and efficient method for the preparation of 5-arylselanyl-1H-1,2,3-triazoles from propiolic acids, diselenides and azides, in which a selanylalkyne was firstly formed via decarboxylative reactions, followed by the intermolecular copper-catalyzed azide-alkyne cycloaddition reaction (CuAAC) to afford the desired products [53]. Wang et al. described the use of $\mathrm{PhSO}_{2} \mathrm{SePh}$ as an electrophile in the copper (I)-catalyzed interrupted click reaction of phenylacetylene with benzylazide, giving 5-arylselanyl-1H-1,2,3-triazole in 71\% yield [54]. Manarin et al. developed a general method for the synthesis of 4-arylselanyl-1H-1,2,3-triazoles via a CuAAC reaction between organic azides and a terminal selanylalkyne, generated by the in situ deprotection of the silyl group [55]. The synthesis of 1-benzyl-4-(phenylselanyl)-1H-1,2,3-triazole was described by Saraiva et al., in which ethynyl(phenyl)selenide underwent $\mathrm{CuAAC}$ with benzylazide to give the product in $84 \%$ yield [56]. However, for the synthesis of ethynyl(phenyl)selenide, the protocol available at the time to achieve such starting material was described by Braga et al., dating from 1994 [57]. Recently, we have developed an alternative way to prepare these terminal alkynes containing selenium and sulfur, starting from chalcogencontaining alkynyl carbinols [58]. In this study, during the preparation of the terminal selanylalkynes, it was observed that in air without solvent, these compounds showed signals of decomposition. Furthermore, we observed that in a hexane solution, the terminal selanylalkynes were stable in the presence of air. With these observations in mind, we wondered if selanylalkynylcarbinols could serve as starting materials for the synthesis of a range of 4-arylselanyl-1H-1,2,3-triazoles in a one-pot procedure.

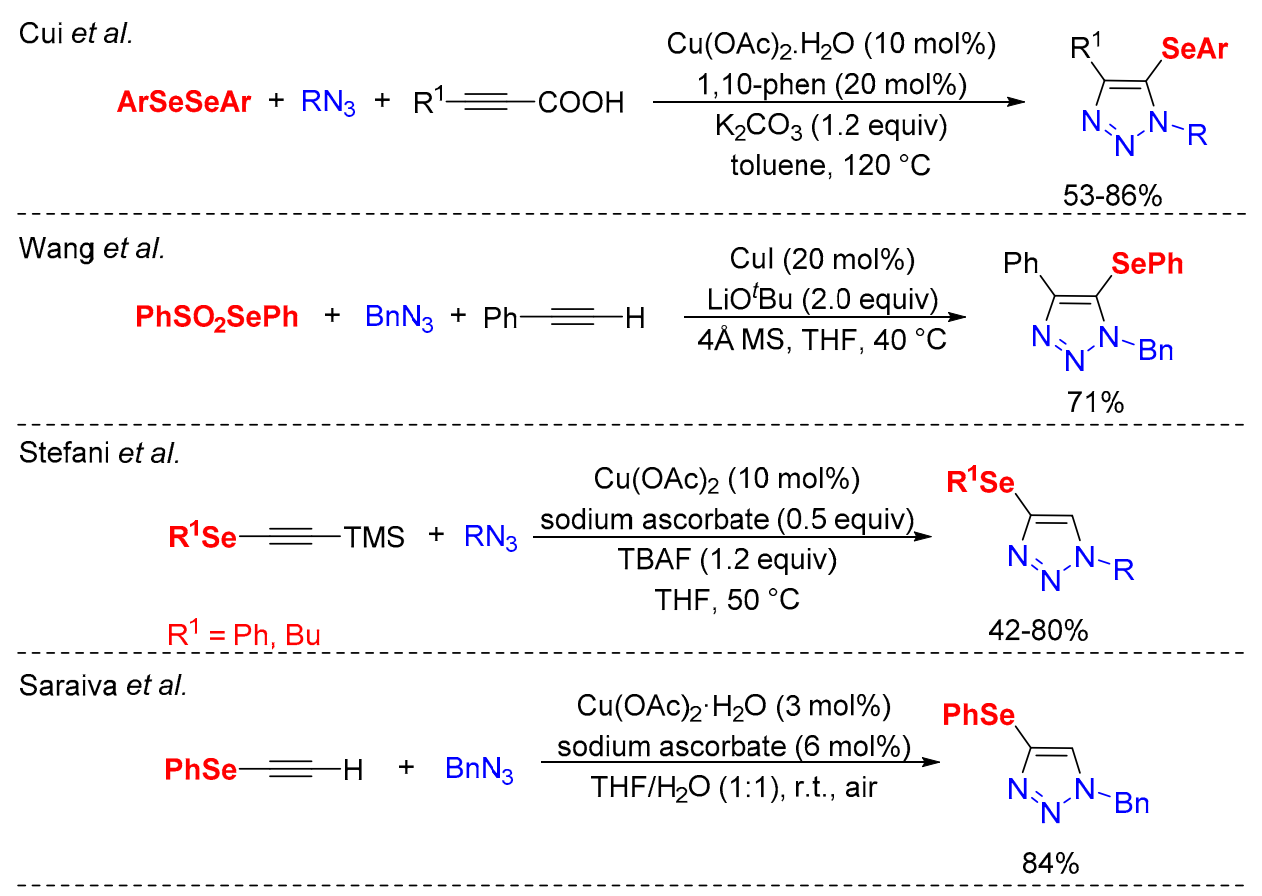

Figure 1. Previous protocols to prepare 5-arylselanyl- and 4-arylselanyl-1H-1,2,3-triazoles.

In view of the above, and in continuation to our research endeavors in the development of efficient and selective methods to access functionalized selanyl-1,2,3-triazoles, we report herein a one-pot strategy to prepare 4-arylselanyl-1H-1,2,3-triazoles, starting from easily available and bench-stable selanylalkynylcarbinols and organic azides (Scheme 1). 


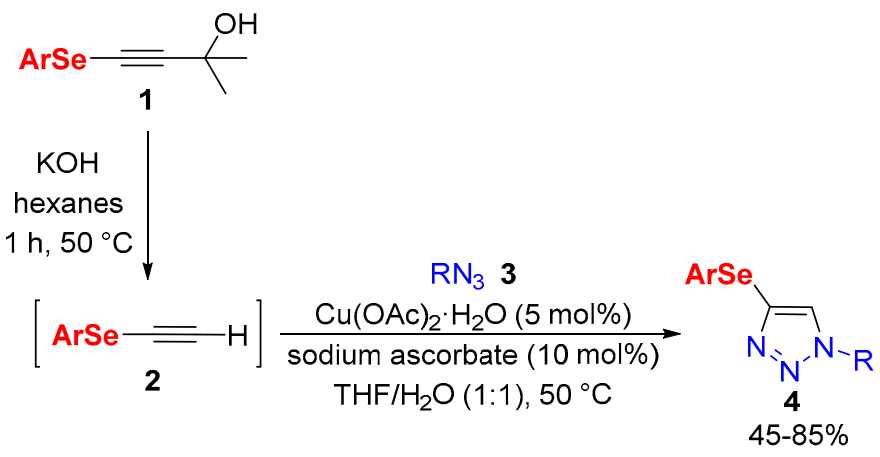

Scheme 1. Synthesis of 4-arylselanyl-1H-1,2,3-triazoles from selenium-containing carbinols.

\section{Results and Discussion}

Initial experiments to optimize the reaction conditions were carried out using 2methyl-4-(phenylselanyl)but-3-yn-2-ol 1a and 1-azido-4-chlorobenzene 3a as standard reaction substrates (Table 1). The key step of the protocol involved the deprotection of the hydroxypropargyl selenide $1 \mathrm{a}(1 \mathrm{mmol})$ to give the terminal selanylalkyne intermediate 2a according to a retro-Favorskii reaction mechanism. For this reaction, we used our previously optimized conditions $\left(\mathrm{KOH} /\right.$ hexanes, $\left.50{ }^{\circ} \mathrm{C}\right)$ [58], and after $1 \mathrm{~h}$, the propargyl alcohol 1a (monitored by TLC) was completely consumed. Then, the crude reaction mixture was allowed to reach room temperature, and a 1:1 mixture of THF/ $\mathrm{H}_{2} \mathrm{O}(1.0 \mathrm{~mL})$ was added, followed by 1-azido-4-chlorobenzene $3 \mathrm{a}(0.5 \mathrm{mmol})$, sodium ascorbate $(10 \mathrm{~mol} \%)$ and $\mathrm{Cu}(\mathrm{OAc})_{2} \cdot \mathrm{H}_{2} \mathrm{O}(5 \mathrm{~mol} \%)$. The resulting mixture was then stirred at $50{ }^{\circ} \mathrm{C}$ until all the azide $3 \mathrm{a}$ was not observable anymore by TLC, $8.0 \mathrm{~h}$. Under these conditions, the expected 4-phenylselanyl-1H-1,2,3-triazole 4 a was obtained in $85 \%$ yield.

Table 1. Optimization of the reaction conditions. ${ }^{\text {a }}$
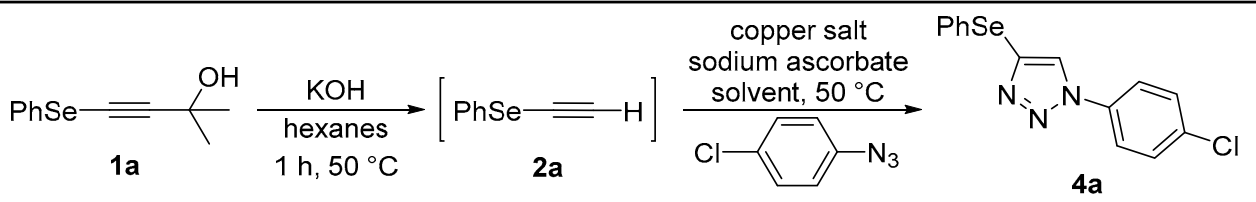

$3 a$

\begin{tabular}{|c|c|c|c|}
\hline Entry & Copper Salt & Solvent & Yield (\%) $b$ \\
\hline 1 & $\mathrm{Cu}(\mathrm{OAc})_{2} \cdot \mathrm{H}_{2} \mathrm{O}$ & $\mathrm{THF} / \mathrm{H}_{2} \mathrm{O}$ & 85 \\
\hline 2 & $\mathrm{CuI}$ & $\mathrm{THF} / \mathrm{H}_{2} \mathrm{O}$ & 60 \\
\hline $3^{c}$ & CuI & DMSO & 32 \\
\hline 4 & $\mathrm{CuO}_{\text {nps }}$ & $\mathrm{THF} / \mathrm{H}_{2} \mathrm{O}$ & traces \\
\hline 5 & $\mathrm{CuCl}_{2}$ & $\mathrm{THF} / \mathrm{H}_{2} \mathrm{O}$ & 75 \\
\hline 6 & $\mathrm{Cu}(\mathrm{OAc})_{2} \cdot \mathrm{H}_{2} \mathrm{O}$ & THF & - \\
\hline $7^{\mathrm{d}}$ & $\mathrm{Cu}(\mathrm{OAc})_{2} \cdot \mathrm{H}_{2} \mathrm{O}$ & $\mathrm{THF} / \mathrm{H}_{2} \mathrm{O}$ & 40 \\
\hline $8^{\mathrm{e}}$ & $\mathrm{Cu}(\mathrm{OAc})_{2} \cdot \mathrm{H}_{2} \mathrm{O}$ & $\mathrm{THF} / \mathrm{H}_{2} \mathrm{O}$ & 65 \\
\hline $9^{\mathrm{f}}$ & $\mathrm{Cu}(\mathrm{OAc})_{2} \cdot \mathrm{H}_{2} \mathrm{O}$ & $\mathrm{THF} / \mathrm{H}_{2} \mathrm{O}$ & 40 \\
\hline $10^{\mathrm{g}}$ & $\mathrm{Cu}(\mathrm{OAc})_{2} \cdot \mathrm{H}_{2} \mathrm{O}$ & $\mathrm{THF} / \mathrm{H}_{2} \mathrm{O}$ & 50 \\
\hline
\end{tabular}

a General reaction conditions: Compound 1a $(1 \mathrm{mmol})$ was subjected to the retro-Favorskii reaction [58]. After its completion (followed by TLC), azide $3 a\left(0.5\right.$ equiv) was added, followed by sodium ascorbate $(10 \mathrm{~mol} \%)$, the copper salt $(5 \mathrm{~mol} \%), \mathrm{THF}(0.5 \mathrm{~mL})$ and $\mathrm{H}_{2} \mathrm{O}(0.5 \mathrm{~mL})$. The resulting mixture was stirred for $8 \mathrm{~h}$ at $50{ }^{\circ} \mathrm{C}$. ${ }^{\mathrm{b}}$ Yields of isolated product $4 \mathrm{a} .{ }^{\mathrm{c}}$ Reaction performed in the absence of sodium ascorbate and in the presence of $\mathrm{Et}_{3} \mathrm{~N}$ (1 equiv). ${ }^{\mathrm{d}}$ Reaction performed using $3 \mathrm{~mol} \%$ of $\mathrm{Cu}(\mathrm{OAc})_{2} \cdot \mathrm{H}_{2} \mathrm{O}$ and 6 mol\% of sodium ascorbate. ${ }^{\mathrm{e}}$ Argon atmosphere was employed. ${ }^{\mathrm{f}}$ Reaction performed at room temperature. ${ }^{\mathrm{g}}$ Reaction performed using 1 equiv. of azide $3 \mathbf{a}$.

From this promising result, some additional experiments were conducted, aiming to increase the yield of $4 \mathbf{a}$ while reducing the reaction time (Table 1). Firstly, different copper species $\left(\mathrm{CuI}, \mathrm{CuO}_{\text {nps }}\right.$ and $\mathrm{CuCl}_{2}$ ) were tested under the same conditions, but in all the cases we observed lower yields than that obtained using $\mathrm{Cu}(\mathrm{OAc})_{2} \cdot \mathrm{H}_{2} \mathrm{O}$ (Table 1 , entry 1 vs. entries 2-5). For instance, the use of $\mathrm{CuI}$ gave $4 \mathrm{a}$ in $60 \%$ yield under the conditions of entry 
1, and only $32 \%$ using $\mathrm{Et}_{3} \mathrm{~N}$ in the place of sodium ascorbate and in DMSO as the solvent

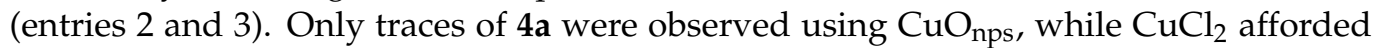
the expected product in $75 \%$ yield (Table 1, entries 4 and 5). The presence of water in the reaction medium was essential for the success of the reaction once no product was observed using dry THF (Table 1, entry 6). The use of lower amounts of both, sodium ascorbate $(6 \mathrm{~mol} \%)$ and $\mathrm{Cu}(\mathrm{OAc})_{2} \cdot \mathrm{H}_{2} \mathrm{O}(3 \mathrm{~mol} \%)$, or an argon atmosphere, negatively influenced the reaction, affording $4 \mathrm{a}$ in $40 \%$ and $65 \%$ yield, respectively (Table 1, entries 7 and 8 ). The influence of the temperature and the stoichiometry of the reagents was evaluated. At room temperature, the pre-formed terminal selanylacetylene 1 a reacted with azide $3 a$ to give 4a in 40\% yield (Table 1, entry 9). A moderate result was also observed when equivalent amounts of $\mathbf{2} \mathbf{a}$ and $3 \mathbf{a}$ were reacted, affording $\mathbf{4 a}$ in $50 \%$ yield (Table 1, entry 10).

After analyzing these results, we determined that the best reaction conditions were those reported in Table 1, entry 1: after stirring a mixture of the propargyl alcohol 1a and $\mathrm{KOH}$ in hexanes, the resulting in situ formed terminal alkyne $2 \mathbf{a}$ mixed with the azide $3 \mathbf{a}$ ( 0.5 equiv.) were stirred in the presence of sodium ascorbate $(10 \mathrm{~mol} \%)$ and $\mathrm{Cu}(\mathrm{OAc})_{2} \cdot \mathrm{H}_{2} \mathrm{O}$ ( $5 \mathrm{~mol} \%$ ) in a $1: 1$ mixture of THF and $\mathrm{H}_{2} \mathrm{O}$ as the solvent.

The scope of the proposed methodology was then extended to differently substituted alkynyl selenides $\mathbf{1 b} \mathbf{b} \mathbf{f}$, in the reaction with 1-azido-4-chlorobenzene $\mathbf{3 a}$, aiming to investigate the generality and limitations of the method (Scheme 2). Interesting, there is a little influence of the electronic effect in the reaction, and the presence of electron-donating groups in the para-position of the pendant phenyl increase the reactivity. For instance, electron-rich 4-((4-methoxyphenyl)selanyl)- $\mathbf{1 b}\left(\mathrm{Ar}=4-\mathrm{MeOC}_{6} \mathrm{H}_{4}\right)$ and 2-methyl-4-( $p$-tolylselanyl)but-3yn-2-ol $1 \mathrm{c}\left(\mathrm{Ar}=4-\mathrm{MeC}_{6} \mathrm{H}_{4}\right)$ afforded the respective 4-arylselanyl-1H-1,2,3-triazoles $4 \mathbf{b}$ and $4 \mathrm{c}$ in $75 \%$ and $66 \%$ yield, while the electron-poor one 2-methyl-4-(4-fluoroselanyl)but-3yn-2-ol 1e $\left(\mathrm{Ar}=4-\mathrm{FC}_{6} \mathrm{H}_{4}\right)$ afforded the triazole $4 \mathbf{e}$ in $55 \%$ yield. A remarkable result was obtained in the reaction of 2-methyl-4-(4-bromoselanyl)but-3-yn-2-ol 1d $\left(\mathrm{Ar}=4-\mathrm{BrC}_{6} \mathrm{H}_{4}\right)$, which afforded the bromo-functionalized triazole $4 \mathbf{d}$ (59\% yield), which can be subject to further transformation via Sonogashira cross-coupling reaction. A decrease in yield was observed, however, when the strong electron withdrawing $\mathrm{CF}_{3}$ group was present in the meta-position. Thus, 2-methyl-4-((3-(trifluoromethyl)phenyl)selanyl)but-3-yn-2-ol 1e reacted with $3 \mathrm{a}$ under the optimal conditions to afford the expected triazole $4 \mathrm{f}$ in $45 \%$ yield (Scheme 2).

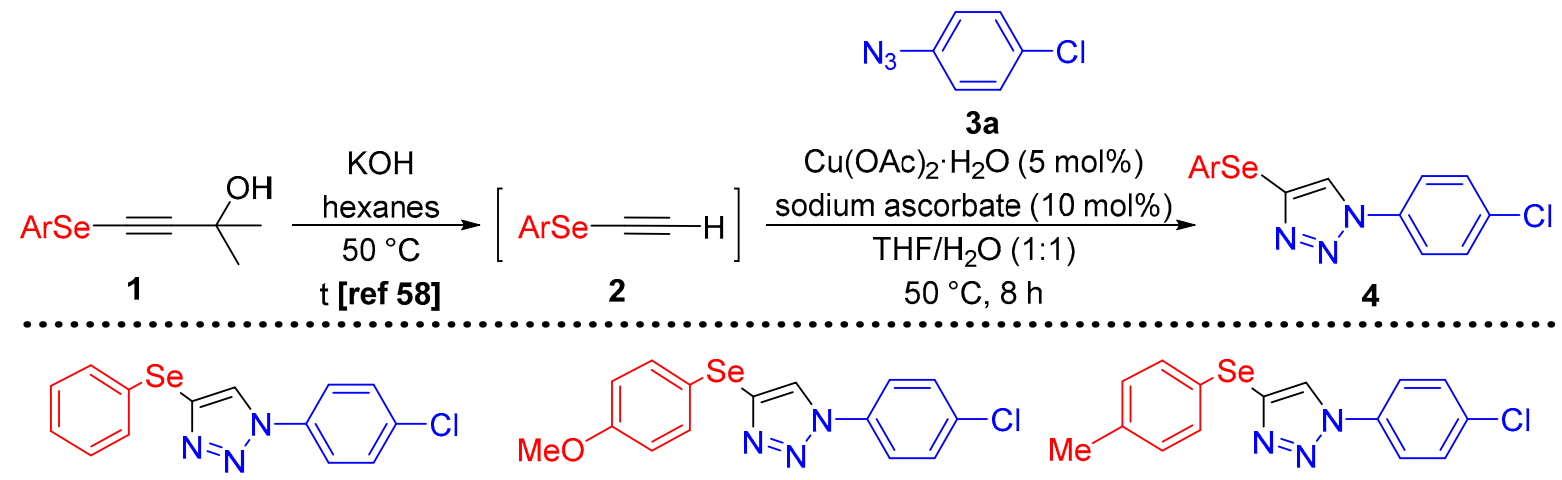

$4 a, 85 \%$

4b, $75 \%$

4c, $66 \%$
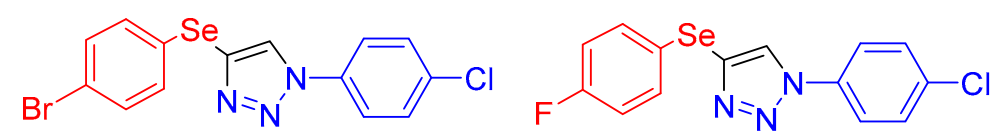

4 e, $55 \%$

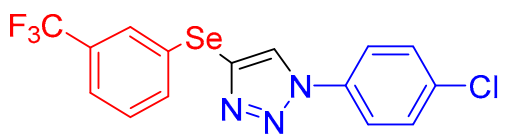

4f, $45 \%$

Scheme 2. 4-Arylselanyl-1H-1,2,3-triazoles 4a-f: scope of arylselanyl carbinols $\mathbf{1}$. 
Subsequently, we investigated the reactivity of a variety of organic azides 3 with 2-methyl-4-(phenylselanyl)but-3-yn-2-ol 1a under the best reaction conditions (Scheme 3). As for the alkynyl selenide counterpart, electronic effect does not seem to influence the reactivity of the para-substituted aryl azides 3. For instance, the electron-rich 1-azido-4methoxybenzene $3 \mathbf{b}\left(\mathrm{R}=4\right.$ - $\left.\mathrm{MeOC}_{6} \mathrm{H}_{4}\right)$ and the electron-deficient 1-azido-4-fluorobenzene $3 \mathrm{c}\left(\mathrm{R}=4-\mathrm{FC}_{6} \mathrm{H}_{4}\right)$ afforded the respective triazoles $4 \mathrm{~g}$ and $4 \mathrm{~h}$ in $82 \%$ and $79 \%$ yield after reaction with $2 \mathrm{a}$. A similarly good result was observed from the 4-iodo-substituted azide $3 \mathbf{d}$, affording the iodo-containing triazole $4 \mathbf{i}$ in $77 \%$ yield, which could be subject to further modifications, as mentioned for $4 \mathbf{d}$. The presence of a fluoro atom at the ortho-position, like in $3 \mathbf{e}\left(\mathrm{R}=2-\mathrm{FC}_{6} \mathrm{H}_{4}\right)$, slightly affected the reactivity, and the respective product $\mathbf{4 j}$ was isolated in $56 \%$ yield. Interestingly, the strong electron-withdrawing nitro group positively affected the reaction, and 1-azido-3-nitrobenzene $3 f\left(\mathrm{R}=3-\mathrm{NO}_{2} \mathrm{C}_{6} \mathrm{H}_{4}\right)$ gave $4 \mathbf{k}$ in $75 \%$ yield. (Azidomethyl)benzene $\mathbf{3 g}$ was a suitable substrate in the reaction with 2a (generated in situ from 1a), affording 1-benzyl-4-(phenylselanyl)-1-1,2,3-triazole 41 in $72 \%$ yield. Molecular hybridization is a valuable strategy in medicinal chemistry, allowing access to potent multitarget drugs [59,60]. In view of the recognized bioactivity of both, organoselenium and triazole units, we decided to explore the functionalization of two known nuclei, 7-chloroquinoline and Zidovudine, which could present interesting pharmacological properties to be explored. Thus, 4-azido-7-chloroquinoline $3 \mathrm{~h}$ reacted with $2 \mathrm{a}$ to give the 7 -chloroquinoline-derivative $4 \mathrm{~m}$ in $80 \%$ yield, while the azido-derivative of Zidovudine $3 \mathbf{i}$ was converted to the respective triazole $4 \mathbf{n}$ in $48 \%$ yield.

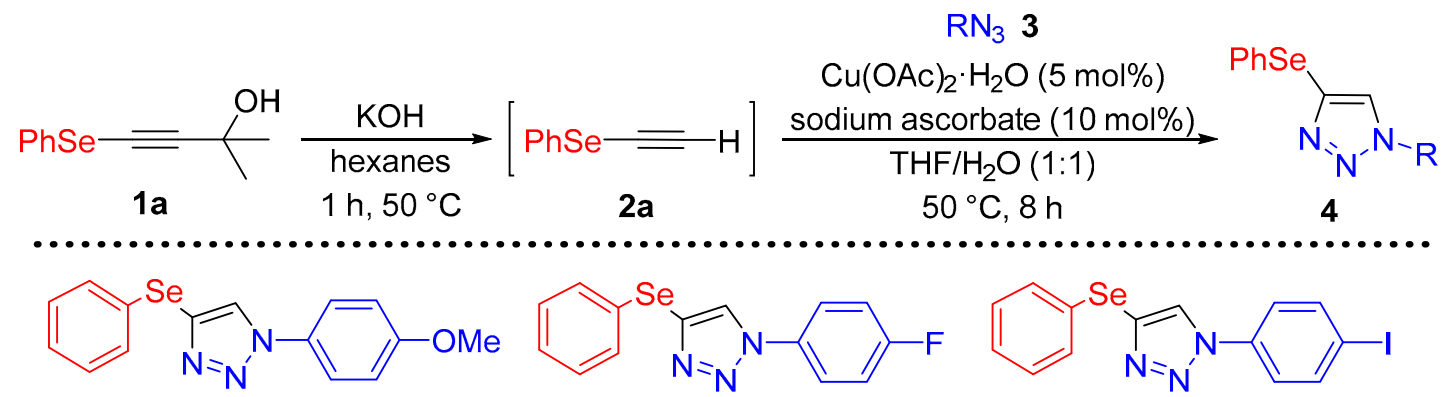

4g, $82 \%$

4h, $79 \%$

4i, $77 \%$<smiles>Fc1ccccc1-n1cc([Se]c2ccccc2)nn1</smiles><smiles>O=[N+]([O-])c1cccc(-n2cc([Se]c3ccccc3)nn2)c1</smiles><smiles>c1ccc(Cn2cc([Se]c3ccccc3)nn2)cc1</smiles>

4j, $56 \%$

4k, $75 \%$

4I, $72 \%$<smiles>Clc1ccc2c(-n3cc([Se]c4ccccc4)nn3)ccnc2c1</smiles><smiles>Cc1cn(C2CC(n3cc([Se]c4ccccc4)nn3)C(CO)O2)c(=O)[nH]c1=O</smiles>

Scheme 3. 4-Arylselanyl-1H-1,2,3-triazoles 4g-n: scope of azides 3.

While performing these CuAAc reactions, the formation of a by-product was observed, with a retention factor (RF) in thin layer chromatography remarkably similar to product 4 . This by-product was isolated and characterized as the triazole derived from the reaction of the organyl azide 3 with two equiv. of alkynyl selenide 2a. Unfortunately, the purification of this by-product is extremely difficult because of the similarity of RF with the main product 4 . Fortunately, the by-products $5 \mathbf{a}$ and $\mathbf{5 b}$ could be isolated, even if in low yields, and were fully characterized (Scheme 4). A possible explanation for the formation of 
alkynes 5 is the presence of the remaining strong base $(\mathrm{KOH})$, used in the first step of the reaction (the retro-Favorskii of propargyl alcohol $\mathbf{2 a}$ ), according to the previously observed by Li, Zhang et al. [61].

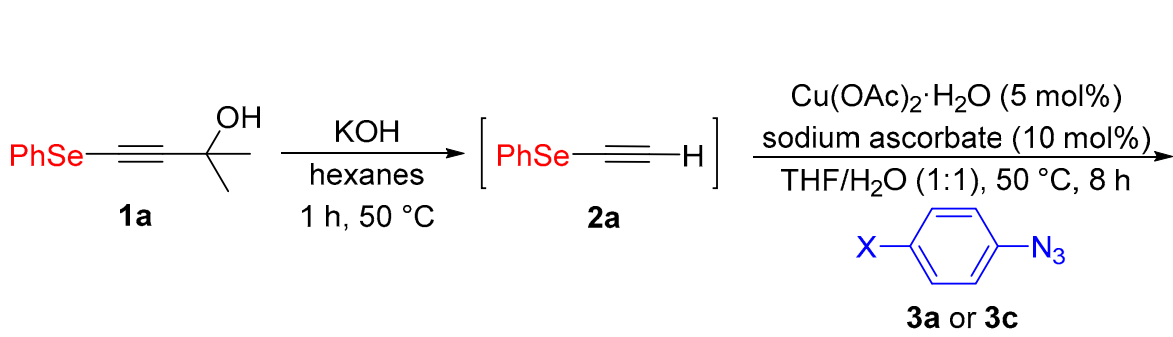

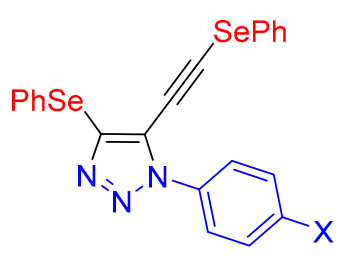

5a, $\mathrm{X}=\mathrm{Cl}, 17 \%$ 5b, $X=F, 15 \%$

Scheme 4. By-products $5 \mathbf{a}$ and $5 \mathbf{b}$ from the reaction of $3 \mathbf{a}$ or $3 \mathbf{c}$ with $2 \mathbf{a}$ generated in situ.

\section{Materials and Methods}

Reactions were carried out in a two-necked round-bottomed flask with a Teflon-coated magnetic stirring bar. Solvents and reagents were used as received unless otherwise noted. The reactions were monitored by TLC performed by using Merck silica gel (60 F254), $0.25 \mathrm{~mm}$ thickness. For visualization, TLC plates were either placed under UV light, or stained with iodine vapor or $5 \%$ vanillin in $10 \% \mathrm{H}_{2} \mathrm{SO}_{4}$ under heating. Column chromatography was performed by using Merck silica gel (230-400 mesh). Carbon-13 nuclear magnetic resonance spectra $\left({ }^{13} \mathrm{C}\right.$ NMR) were obtained at $75 \mathrm{MHz}$ on a Bruker DPX 300 spectrometer and at $100 \mathrm{MHz}$ on a Bruker Avance III HD 400 spectrometer. Spectra were recorded in $\mathrm{CDCl}_{3}$ solutions. Chemical shifts are reported in ppm, referenced to tetramethylsilane (TMS) as the external reference $\left({ }^{1} \mathrm{H} \mathrm{NMR}\right)$ or to the solvent peak of $\mathrm{CDCl}_{3}$ $\left({ }^{13} \mathrm{C}\right.$ NMR). Coupling constants $(J)$ are reported in Hertz. Abbreviations to denote the multiplicity of a particular signal are s (singlet), d (doublet), t (triplet), dd (double doublet), q (quartet) and $\mathrm{m}$ (multiplet). High resolution mass spectra (HRMS) were recorded on a Bruker Micro TOF-QII spectrometer 10416. Reagents 2-methyl-3-butyn-2-ol and selenium powder were purchased from Sigma-Aldrich. The starting materials selanylalkynylcarbinols were synthesized according to previous literature [58]. ${ }^{1} \mathrm{H}$ and ${ }^{13} \mathrm{C}$ NMR spectra of all compounds are available in Supplementary Materials.

\section{General Procedure for the Synthesis of 4-Arylselanyl-1H-1,2,3-triazoles 4}

Arylselanyl carbinol 1 (1.0 mmol), KOH (1.1 mmol, $0.062 \mathrm{~g})$ and hexanes $(3.0 \mathrm{~mL})$ were added to a $25 \mathrm{~mL}$ two-necked round-bottomed flask equipped with a reflux condenser. The system was then immersed in a preheated oil bath at $50{ }^{\circ} \mathrm{C}$ and stirred at this temperature for 1 to $5 \mathrm{~h}$ (the consumption of carbinol 1 was followed by TLC) [58]. Then, $0.5 \mathrm{mmol}$ of the appropriate azide $3, \mathrm{Cu}(\mathrm{OAc})_{2} \cdot \mathrm{H}_{2} \mathrm{O}(0.025 \mathrm{mmol})$, sodium ascorbate $(0.5 \mathrm{mmol}), \mathrm{THF}$ $(0.5 \mathrm{~mL})$ and $\mathrm{H}_{2} \mathrm{O}(0.5 \mathrm{~mL})$ were added to the reaction flask. The resulting solution was stirred at $50{ }^{\circ} \mathrm{C}$ for $8 \mathrm{~h}$. Then, a saturated solution of $\mathrm{NH}_{4} \mathrm{Cl}(10 \mathrm{~mL})$ was added, followed by the addition of EtOAc $(10 \mathrm{~mL})$. The organic layer was separated, and the aqueous phase was extracted with EtOAc $(3 \times 10 \mathrm{~mL})$, dried over $\mathrm{MgSO}_{4}$, and the solvent was evaporated under reduced pressure. The crude product was purified by column chromatography on silica gel with a mixture of hexane/ethyl acetate (9:1) as eluent. Spectral data for the prepared products are listed below.

1-(4-Chlorophenyl)-4-(phenylselanyl)-1H-1,2,3-triazole (4a): Pale yellow solid, mp: $105-107^{\circ} \mathrm{C}$. Yield: $0.142 \mathrm{~g}(85 \%) .{ }^{1} \mathrm{H} \mathrm{NMR}\left(300 \mathrm{MHz}, \mathrm{CDCl}_{3}\right) \delta: 8.05(\mathrm{~s}, 1 \mathrm{H}), 7.67(\mathrm{~d}, J=8.9 \mathrm{~Hz}, 2 \mathrm{H})$, 7.54-7.47 (m, 4H), 7.26-7.24 (m, 3H). $\left.{ }^{13} \mathrm{C} \mathrm{NMR} \mathrm{(75} \mathrm{MHz,} \mathrm{CDCl}_{3}\right)$ \%: 135.0, 134.8, 133.7, 131.9, $129.9,129.4,127.6,126.3,124.4,121.6$. HRMS Calcd. for $\mathrm{C}_{14} \mathrm{H}_{10} \mathrm{ClN}_{3} \mathrm{Se}[\mathrm{M}+\mathrm{H}]^{+}: 335.9799$. Found: 335.9802.

1-(4-Chlorophenyl)-4-((4-methoxyphenyl)selanyl)-1H-1,2,3-triazole (4b): Yellow solid, mp:

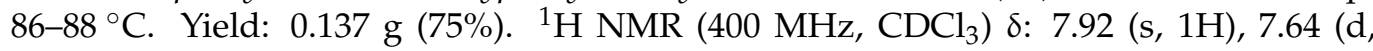


$J=8.9 \mathrm{~Hz}, 2 \mathrm{H}), 7.57(\mathrm{~d}, J=8.8 \mathrm{~Hz}, 2 \mathrm{H}), 7.47(\mathrm{~d}, J=8.9 \mathrm{~Hz}, 1 \mathrm{H}), 6.82(\mathrm{~d}, J=8.8 \mathrm{~Hz}, 2 \mathrm{H})$, 3.78 (s, 3H). ${ }^{13} \mathrm{C}$ NMR (100 MHz, $\left.\mathrm{CDCl}_{3}\right) \delta: 159.8,135.4,135.2,134.7,129.9,125.1,124.3$, 121.6, 119.3, 115.1, 55.3. HRMS Calcd. for $\mathrm{C}_{15} \mathrm{H}_{12} \mathrm{ClN}_{3} \mathrm{OSe}\left[\mathrm{M}-\mathrm{N}_{2}+\mathrm{H}\right]^{+}$: 337.9843. Found: 337.9843.

1-(4-Chlorophenyl)-4-(p-tolylselanyl)-1H-1,2,3-triazole (4c): Yellow solid, mp: $74-75{ }^{\circ} \mathrm{C}$. Yield: $0.115 \mathrm{~g}(66 \%) .{ }^{1} \mathrm{H}$ NMR $\left(400 \mathrm{MHz} \mathrm{CDCl}_{3}\right) \delta: 7.87(\mathrm{~s}, 1 \mathrm{H}), 7.58(\mathrm{~d}, J=8.9 \mathrm{~Hz}, 2 \mathrm{H}), 7.42-7.39$ $(\mathrm{m}, 4 \mathrm{H}), 7.01(\mathrm{~d}, J=7.9 \mathrm{~Hz}, 2 \mathrm{H}) .{ }^{13} \mathrm{C} \mathrm{NMR}\left(100 \mathrm{MHz}, \mathrm{CDCl}_{3}\right) \delta: 137.9,133.7,132.8,130.8$, $130.2,130.0,129.5,125.6,124.4,121.6,21.0$. HRMS Calcd. for $\mathrm{C}_{15} \mathrm{H}_{12} \mathrm{ClN}_{3} \mathrm{Se}\left[\mathrm{M}-\mathrm{N}_{2}+\mathrm{H}\right]^{+}$: 321.9894. Found: 321.9875.

4-((4-Bromophenyl)selanyl)-1-(4-chlorophenyl)-1H-1,2,3-triazole (4d): Yellow solid, mp:

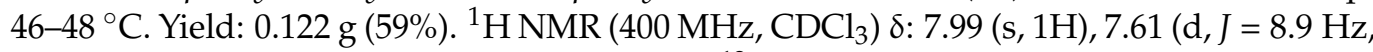
2H), $7.43(\mathrm{~d}, J=8.9 \mathrm{~Hz}, 2 \mathrm{H}), 7.33-7.28(\mathrm{~m}, 4 \mathrm{H}) .{ }^{13} \mathrm{C} \mathrm{NMR}\left(100 \mathrm{MHz}, \mathrm{CDCl}_{3}\right) \delta:$ 135.0, 133.5, $132.4,132.0,130.0,129.4,128.9,127.6,126.4,121.7$. HRMS Calcd. for $\mathrm{C}_{14} \mathrm{H}_{9} \mathrm{BrClN}_{3} \mathrm{Se}\left[\mathrm{M}-\mathrm{N}_{2}\right.$ $+\mathrm{H}]^{+}:$385.8840. Found: 385.8838 .

1-(4-Chlorophenyl)-4-((4-fluorophenyl)selanyl)-1H-1,2,3-triazole (4e): Yellow solid, mp: 48-50 ${ }^{\circ} \mathrm{C}$. Yield: $0.097 \mathrm{~g}(55 \%) .{ }^{1} \mathrm{H} \mathrm{NMR}\left(400 \mathrm{MHz}, \mathrm{CDCl}_{3}\right) \delta: 8.02(\mathrm{~s}, 1 \mathrm{H}), 7.67(\mathrm{~d}, J=8.7 \mathrm{~Hz}$, $2 \mathrm{H}), 7.56(\mathrm{dd}, J=8.6$ and $5.3 \mathrm{~Hz}, 2 \mathrm{H}), 7.49(\mathrm{~d}, J=8.7 \mathrm{~Hz}, 2 \mathrm{H}), 6.97(\mathrm{t}, J=8.6 \mathrm{~Hz}, 2 \mathrm{H}) .{ }^{13} \mathrm{C}$ $\operatorname{NMR}\left(100 \mathrm{MHz}, \mathrm{CDCl}_{3}\right) \delta: 162.6\left(\mathrm{~d}, J_{\mathrm{C}-\mathrm{F}}=248.1 \mathrm{~Hz}\right), 135.0,134.9,134.7\left(\mathrm{~d}, J_{\mathrm{C}-\mathrm{F}}=8.0 \mathrm{~Hz}\right)$, $131.1,130.0,125.9,124.1\left(\mathrm{~d}, J_{\mathrm{C}-\mathrm{F}}=3.5 \mathrm{~Hz}\right), 121.6,116.6\left(\mathrm{~d}, J_{\mathrm{C}-\mathrm{F}}=21.6 \mathrm{~Hz}\right)$. HRMS Calcd. for $\mathrm{C}_{14} \mathrm{H}_{9} \mathrm{ClFN}_{3}$ Se $\left[\mathrm{M}-\mathrm{N}_{2}+\mathrm{H}\right]^{+}:$325.9643. Found: 325.9636 .

1-(4-Chlorophenyl)-4-((3-(trifluoromethyl)phenyl)selanyl)-1H-1,2,3-triazole (4f): Yellow solid, mp: $45-47{ }^{\circ} \mathrm{C}$. Yield: $0.091 \mathrm{~g}(45 \%) .{ }^{1} \mathrm{H}$ NMR (400 MHz, $\left.\mathrm{CDCl}_{3}\right)$ 8: 8.05 (s, 1H), 7.69 (s, $1 \mathrm{H}), 7.63-7.60(\mathrm{~m}, 3 \mathrm{H}), 7.44-7.41(\mathrm{~m}, 3 \mathrm{H}), 7.29(\mathrm{t}, J=7.8 \mathrm{~Hz}, 1 \mathrm{H}) .{ }^{13} \mathrm{C}$ NMR $(100 \mathrm{MHz}$, $\left.\mathrm{CDCl}_{3}\right) \delta: 135.1,135.0,134.9,132.5,131.6\left(\mathrm{q}, J_{\mathrm{C}-\mathrm{F}}=32.9 \mathrm{~Hz}\right), 131.3,130.1,129.7,128.1(\mathrm{q}$, $\left.J_{C-F}=3.6 \mathrm{~Hz}\right), 126.8,124.3\left(q, J_{C-F}=3.7 \mathrm{~Hz}\right), 123.5\left(q, J_{C-F}=272.7 \mathrm{~Hz}\right), 121.7$. HRMS Calcd. for $\mathrm{C}_{15} \mathrm{H}_{9} \mathrm{ClF}_{3} \mathrm{~N}_{3} \mathrm{Se}\left[\mathrm{M}-\mathrm{N}_{2}+\mathrm{H}\right]^{+}:$374.96431. Found: 374.9643 .

1-(4-Methoxyphenyl)-4-(phenylselanyl)-1H-1,2,3-triazole (4g): [58] Light orange solid, mp:

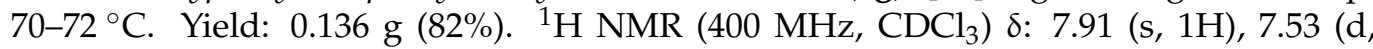
$J=8.8 \mathrm{~Hz}, 2 \mathrm{H}), 7.43-7.42(\mathrm{~m}, 2 \mathrm{H}), 7.19-7.16(\mathrm{~m}, 3 \mathrm{H}), 6.92(\mathrm{~d}, J=8.9 \mathrm{~Hz}, 2 \mathrm{H}), 3.77(\mathrm{~s}, 3 \mathrm{H})$. ${ }^{13} \mathrm{C} \mathrm{NMR}\left(100 \mathrm{MHz} \mathrm{CDCl}_{3}\right) \delta: 160.0,132.9,132.6,131.7,129.3,127.4,126.7,124.8,122.1$, $114.8,55.6$.

1-(4-Fluorophenyl)-4-(phenylselanyl)-1H-1,2,3-triazole (4h): white solid, mp: $78-80{ }^{\circ} \mathrm{C}$. Yield: $0.126 \mathrm{~g}(79 \%) .{ }^{1} \mathrm{H}$ NMR $\left(300 \mathrm{MHz}, \mathrm{CDCl}_{3}\right) \delta: 8.02(\mathrm{~s}, 1 \mathrm{H}), 7.72-7.68(\mathrm{~m}, 2 \mathrm{H}), 7.54-7.51$

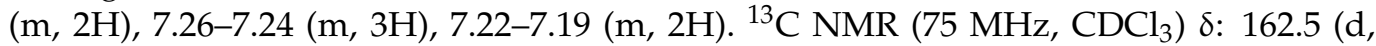
$\left.J_{\mathrm{C}-\mathrm{F}}=249.6 \mathrm{~Hz}\right), 133.4,132.8\left(\mathrm{~d}, J_{\mathrm{C}-\mathrm{F}}=3.4 \mathrm{~Hz}\right), 131.9,130.0,129.4,127.5,126.6,122.5(\mathrm{~d}$, $\left.J_{C-F}=8.7 \mathrm{~Hz}\right), 116.7\left(\mathrm{~d}, J_{\mathrm{C}-\mathrm{F}}=23.2 \mathrm{~Hz}\right)$. HRMS Calcd. for $\mathrm{C}_{14} \mathrm{H}_{10} \mathrm{FN}_{3} \mathrm{Se}[\mathrm{M}+\mathrm{H}]^{+}: 320.0097$. Found: 320.0099.

1-(4-Iodophenyl)-4-(phenylselanyl)-1H-1,2,3-triazole (4i): white solid, mp: $124-126^{\circ} \mathrm{C}$. Yield: $0.164 \mathrm{~g}(77 \%) .{ }^{1} \mathrm{H}$ NMR $\left(300 \mathrm{MHz}, \mathrm{CDCl}_{3}\right) \delta: 8.05$ (s, 1H), $7.83(\mathrm{~d}, J=8.7 \mathrm{~Hz}, 2 \mathrm{H}), 7.54-7.47$ $(\mathrm{m}, 4 \mathrm{H}), 7.26-7.24(\mathrm{~m}, 3 \mathrm{H}) .{ }^{13} \mathrm{C} \mathrm{NMR}\left(75 \mathrm{MHz} \mathrm{CDCl}_{3}\right) \delta: 138.8,136.1,133.8,131.9,129.9$, 129.4, 127.6, 126.1, 121.9, 94.0. HRMS Calcd. for $\mathrm{C}_{14} \mathrm{H}_{10} \mathrm{IN}_{3} \mathrm{Se}[\mathrm{M}+\mathrm{H}]^{+}:$427.9157. Found: 427.9160 .

1-(2-Fluorophenyl)-4-(phenylselanyl)-1H-1,2,3-triazole (4j): Yellow solid, mp: $60-62{ }^{\circ} \mathrm{C}$. Yield: 0.089 g. (56\%). ${ }^{1} \mathrm{H}$ NMR $\left(400 \mathrm{MHz}, \mathrm{CDCl}_{3}\right) \delta: 7.40-7.38(\mathrm{~m}, 2 \mathrm{H}), 7.28-7.15(\mathrm{~m}, 4 \mathrm{H})$, 6.94-6.90 (m, 1H), 6.86-6.82 (m, 1H), 6.57-6.53 (m, 1H). ${ }^{13} \mathrm{C} \mathrm{NMR}\left(100 \mathrm{MHz}, \mathrm{CDCl}_{3}\right) \delta$ : $155.3\left(\mathrm{~d}, J_{\mathrm{C}-\mathrm{F}}=255.8 \mathrm{~Hz}\right), 136.4,133.2,132.6,131.9\left(\mathrm{~d}, J_{\mathrm{C}-\mathrm{F}}=7.7 \mathrm{~Hz}\right), 129.3,129.2,128.8(\mathrm{~d}$, $\left.J_{\mathrm{C}-\mathrm{F}}=23.9 \mathrm{~Hz}\right), 127.9,126.9,124.8,117.0\left(\mathrm{~d}, J_{\mathrm{C}-\mathrm{F}}=19.2 \mathrm{~Hz}\right)$. HRMS Calcd. for $\mathrm{C}_{14} \mathrm{H}_{10} \mathrm{FN}_{3} \mathrm{Se}$ $[\mathrm{M}+\mathrm{H}]^{+}:$320.0097. Found: 320.0097 .

1-(3-Nitrophenyl)-4-(phenylselanyl)-1H-1,2,3-triazole (4k): Yellow solid, mp: $109-11{ }^{\circ} \mathrm{C}$. Yield: $0.130 \mathrm{~g}(75 \%) .{ }^{1} \mathrm{H}$ NMR $\left(400 \mathrm{MHz}, \mathrm{CDCl}_{3}\right) \delta: 8.50(\mathrm{~s}, 1 \mathrm{H}), 8.24(\mathrm{~d}, J=7.1 \mathrm{~Hz}, 1 \mathrm{H}), 8.11-8.08$ 
$(\mathrm{m}, 2 \mathrm{H}), 7.68(\mathrm{~d}, J=8.1 \mathrm{~Hz}, 1 \mathrm{H}), 7.50-7.49(\mathrm{~m}, 2 \mathrm{H}), 7.21-7.19(\mathrm{~m}, 3 \mathrm{H}) .{ }^{13} \mathrm{C} \mathrm{NMR}(100 \mathrm{MHz}$, $\mathrm{CDCl}_{3}$ ) $\delta: 148.9,137.3,134.9,132.4,131.1,129.5,127.9,126.0$ (2C), 125.9, 123.4, 115.2. HRMS Calcd. for $\mathrm{C}_{14} \mathrm{H}_{10} \mathrm{~N}_{4} \mathrm{O}_{2}$ Se $\left[\mathrm{M}-\mathrm{N}_{2}+\mathrm{H}\right]^{+}$: 318.9981. Found: 318.9979 .

1-Benzyl-4-(phenylselanyl)-1H-1,2,3-triazole (41): [56] White solid, mp: 54-56 ${ }^{\circ} \mathrm{C}$. Yield: $0.113 \mathrm{~g}$ (72\%). ${ }^{1} \mathrm{H}$ NMR (400 MHz, $\left.\mathrm{CDCl}_{3}\right)$ 8: $7.48(\mathrm{~s}, 1 \mathrm{H}), 7.35-7.33(\mathrm{~m}, 2 \mathrm{H}), 7.29-7.25(\mathrm{~m}, 3 \mathrm{H})$, 7.18-7.17 (m, 2H), 7.13-7.10 (m, 3H), 5.45 (s, 2H). $\left.{ }^{13} \mathrm{C} \mathrm{NMR} \mathrm{(100} \mathrm{MHz,} \mathrm{CDCl}_{3}\right) \delta: 134.1$, $132.5,131.3,130.6,129.2,129.1,128.9,128.4,128.1,127.2,54.3$.

7-Chloro-4-(4-(phenylselanyl)-1H-1,2,3-triazol-1-yl)quinoline (4m): Orange solid, mp: 48-50 ${ }^{\circ}$ C. Yield: $0.154 \mathrm{~g}(80 \%) .{ }^{1} \mathrm{H}$ NMR $\left(400 \mathrm{MHz}, \mathrm{CDCl}_{3}\right) \delta: 8.93(\mathrm{~d}, J=4.6 \mathrm{~Hz}, 1 \mathrm{H}), 8.12$ $(\mathrm{d}, J=2.1 \mathrm{~Hz}, 1 \mathrm{H}), 8.01(\mathrm{~s}, 1 \mathrm{H}), 7.84(\mathrm{~d}, J=9.1 \mathrm{~Hz}, 1 \mathrm{H}), 7.52-7.47(\mathrm{~m}, 3 \mathrm{H}), 7.37(\mathrm{~d}, J=4.6 \mathrm{~Hz}$, 1H), 7.21-7.18 (m, 3H). ${ }^{13} \mathrm{C} \mathrm{NMR}\left(100 \mathrm{MHz}, \mathrm{CDCl}_{3}\right) \delta: 151.3,150.1,140.4,136.9,134.1,132.4$, 129.5 (2C), 129.4, 129.1, 128.9, 127.9, 124.3, 120.3, 115.9. HRMS Calcd. For $\mathrm{C}_{17} \mathrm{H}_{12} \mathrm{ClN}_{4} \mathrm{Se}$ $[\mathrm{M}+\mathrm{H}]^{+}:$386.9916. Found: 386.9921 .

1-(5-Hidroxymethyl)-4-(4-phenylselanyl)-1H-1,2,3-triazo-1-yl)tetrahydrofuran-2-yl)-5-methylpyrimidine-2,4(1H, 3H) dione (4n): Yield: $0.108 \mathrm{~g}(48 \%)$; White solid; $\mathrm{mp} 101-103{ }^{\circ} \mathrm{C} ;{ }^{1} \mathrm{H}$ $\operatorname{NMR}\left(\mathrm{CDCl}_{3}, 400 \mathrm{MHz}\right): \delta 11.36(\mathrm{~s}, 1 \mathrm{H}), 8.67(\mathrm{~s}, 1 \mathrm{H}), 7.82(\mathrm{~s}, 1 \mathrm{H}), 7.37(\mathrm{~d}, J=9.0 \mathrm{~Hz}, 2 \mathrm{H})$, 7.32-7.24 (m, 3H), $6.43(\mathrm{t}, J=6.6 \mathrm{~Hz}, 1 \mathrm{H}), 5.45-5.40(\mathrm{~m}, 1 \mathrm{H}), 5,28(\mathrm{t}, J=5.2 \mathrm{~Hz}, 1 \mathrm{H}), 4.25$ $(\mathrm{q}, J=3.5 \mathrm{~Hz}, 1 \mathrm{H}), 3.74-3.62(\mathrm{~m}, 2 \mathrm{H}), 2.82-2.63(\mathrm{~m}, 2 \mathrm{H}), 1.81(\mathrm{~s}, 3 \mathrm{H}) .{ }^{13} \mathrm{C} \mathrm{NMR}\left(\mathrm{CDCl}_{3}\right.$, $100 \mathrm{MHz}$ ): $\delta 163.7 ; 150.4 ; 136.2 ; 130.7 ; 130.2 ; 130.1 ; 129.9 ; 129.5 ; 127.0 ; 109.6 ; 84.3 ; 83.9 ; 60.7$; 59.6; 37.0; 12.2. HRMS Calcd. For $\mathrm{C}_{18} \mathrm{H}_{20} \mathrm{~N}_{5} \mathrm{O}_{4} \mathrm{Se}[\mathrm{M}+\mathrm{H}]^{+}: 450.0676$. Found: 450.0673 .

1-(4-Chlorophenyl)-4-(phenylselanyl)-5-((phenylselanyl)ethynyl)-1H-1,2,3-triazole (5a): White solid, mp: $71-73{ }^{\circ} \mathrm{C}$. Yield: $0.043 \mathrm{~g}(17 \%) .{ }^{1} \mathrm{H}$ NMR $\left(400 \mathrm{MHz}, \mathrm{CDCl}_{3}\right) \delta: 7.71(\mathrm{~d}, \mathrm{~J}=8.9 \mathrm{~Hz}$, 2H), 7.60-7.58 (m, 2H), 7.47-7.43 (m, 4H), 7.33-7.25 (m, 6H). $\left.{ }^{13} \mathrm{C} \mathrm{NMR} \mathrm{(100} \mathrm{MHz,} \mathrm{CDCl}_{3}\right)$ $\delta: 138.0,135.6,134.9,133.1,130.3,130.0,129.7,129.5,129.1,128.2,128.0,127.0,125.2,124.6$, 87.5, 87.5. ${ }^{77}$ Se NMR (76 MHz, $\left.\mathrm{CDCl}_{3}\right) \delta: 301.52,298.40$. HRMS Calcd. for $\mathrm{C}_{22} \mathrm{H}_{14} \mathrm{ClN}_{3} \mathrm{Se}_{2}$ : $[\mathrm{M}+\mathrm{H}]^{+}:$515.9279. Found: 515.9275.

1-(4-Fluorophenyl)-4-(phenylselanyl)-5-((phenylselanyl)ethynyl)-1H-1,2,3-triazole (5b): White solid, mp: $67-69{ }^{\circ} \mathrm{C}$. Yield: $0.037 \mathrm{~g}(15 \%) .{ }^{1} \mathrm{H}$ NMR $\left(400 \mathrm{MHz}, \mathrm{CDCl}_{3}\right) \delta: 7.72(\mathrm{dd}, J=9.0$ and $4.7 \mathrm{~Hz}, 2 \mathrm{H}), 7.61-7.57(\mathrm{~m}, 2 \mathrm{H}), 7.47-7.44(\mathrm{~m}, 2 \mathrm{H}), 7.30-7.24(\mathrm{~m}, 6 \mathrm{H}), 7.16(\mathrm{dd}, J=9.0$ and $8.1 \mathrm{~Hz}, 2 \mathrm{H}) .{ }^{13} \mathrm{C}$ NMR $\left(100 \mathrm{MHz} \mathrm{CDCl}_{3}\right) \delta: 162.9\left(\mathrm{~d}, J_{\mathrm{C}-\mathrm{F}}=250.4 \mathrm{~Hz}\right), 137.8,133.0,132.52$ $\left(\mathrm{d}, J_{\mathrm{C}-\mathrm{F}}=3.2 \mathrm{~Hz}\right), 130.2,129.9,129.4,129.1,128.1,127.9,127.0,125.5\left(\mathrm{~d}, J_{\mathrm{C}-\mathrm{F}}=8.8 \mathrm{~Hz}\right), 125.3$, $116.5\left(\mathrm{~d}, J_{\mathrm{C}-\mathrm{F}}=23.3 \mathrm{~Hz}\right), 87.5,87.1$. HRMS Calcd. for $\mathrm{C}_{22} \mathrm{H}_{14} \mathrm{FN}_{3} \mathrm{Se}_{2}:[\mathrm{M}+\mathrm{H}]^{+}: 499.9575$. Found: 499.9582.

\section{Conclusions}

In summary, we have described a one-pot strategy to prepare 4-arylselanyl- $1 \mathrm{H}-1,2,3-$ triazoles starting from easily prepared and bench-stable selanylalkynylcarbinols. The protocol involves the generation of the terminal selanyl alkynes in situ and afforded the expected selenium-containing triazoles in a selective and efficient way. The use of a one-pot protocol avoids the isolation and purification steps of the reactive terminal selanylalkynes. The strategy was successfully employed in the synthesis of selanyltriazole-functionalized chloroquine and Zidovudine. Further studies are ongoing to better characterize the pharmacological potential of these new compounds.

Supplementary Materials: The following are available online, ${ }^{1} \mathrm{H}$ and ${ }^{13} \mathrm{C}$ NMR spectra of all compounds.

Author Contributions: Conceptualization, E.J.L. and D.A.; methodology, F.B., R.A.B., A.L. and E.F.L.; investigation, F.B., R.A.B., A.L. and E.F.L.; resources, E.J.L., C.S. and D.A.; data curation, E.J.L. and D.A., writing-original draft preparation, R.A.B., A.L. and E.F.L.; writing-review and editing, E.J.L., C.S. and D.A.; visualization, E.J.L., C.S. and D.A.; supervision, E.J.L., C.S. and D.A.; funding acquisition, E.J.L., C.S. and D.A. All authors have read and agreed to the published version of the manuscript. 
Funding: This research received no external funding.

Institutional Review Board Statement: Not applicable.

Informed Consent Statement: Not applicable.

Data Availability Statement: Data supporting the reported results can be found with the main author (D.A.).

Acknowledgments: We are grateful to Conselho Nacional de Desenvolvimento Científico e Tecnológico (CNPq) and Fundação de Amparo à Pesquisa do Estado do Rio Grande do Sul (FAPERGS) (Grant PRONEM 16/2551-0000240-1) for financial support. CNPq is also acknowledged for the fellowship for E.J.L. and D.A. This study was financed in part by the Coordenação de Aperfeiçoamento de Pessoal de Nível Superior-Brasil (CAPES)-Finance Code 001. University of Perugia is acknowledged for the "Accordi Quadro" Fellowship to F.B. The work described in this manuscript is part of the scientific activity of the international multidisciplinary "SeS Redox and Catalysis" network. We are grateful to Thiago Barcellos from University of Caxias do Sul (UCS), Brazil, for providing the HRMS analysis.

Conflicts of Interest: The authors declare no conflict of interests.

Sample Availability: Samples of the compounds 4a-n are available from the authors.

\section{References}

1. Dehaen, W.; Bakulev, V.A. (Eds.) Chemistry of 1,2,3-Triazoles; Topics in Heterocyclic Chemistry; Springer International Publishing: Cham, Switzerland, 2015; Volume 40, ISBN 9783319079615.

2. Themed collection: Click chemistry: Function follows form. Chem. Soc. Rev. 2010, 39, 1221-1407.

3. Bertozzi, C.R. A Decade of Bioorthogonal Chemistry, Themed collection: Bioorthogonal Chemistry in Biology. Acc. Chem. Res. 2011, 44, 651-840. [CrossRef]

4. Costa, G.P.; Baldinotti, R.S.M.; Fronza, M.G.; Nascimento, J.E.R.; Dias, I.F.C.; Sonego, M.S.; Seixas, F.K.; Collares, T.; Perin, G.; Jacob, R.G.; et al. Synthesis, Molecular Docking, and Preliminary Evaluation of 2-(1,2,3-Triazoyl)benzaldehydes as Multifunctional Agents for the Treatment of Alzheimer's Disease. ChemMedChem 2020, 15, 610-622. [CrossRef] [PubMed]

5. Begnini, K.R.; Duarte, W.R.; da Silva, L.P.; Buss, J.H.; Goldani, B.S.; Fronza, M.; Segatto, N.V.; Alves, D.; Savegnago, L.; Seixas, F.K.; et al. Apoptosis Induction by 7-Chloroquinoline-1,2,3-Triazoyl Carboxamides in Triple Negative Breast Cancer Cells. Biomed. Pharmacother. 2017, 91, 510-516. [CrossRef]

6. Xie, J.; Seto, C.T. A Two Stage Click-Based Library of Protein Tyrosine Phosphatase Inhibitors. Bioorg. Med. Chem. 2007, 15, 458-473. [CrossRef]

7. Lee, T.; Cho, M.; Ko, S.-Y.; Youn, H.-J.; Baek, D.J.; Cho, W.-J.; Kang, C.-Y.; Kim, S. Synthesis and Evaluation of 1,2,3-Triazole Containing Analogues of the Immunostimulant $\alpha$-GalCer. J. Med. Chem. 2007, 50, 585-589. [CrossRef] [PubMed]

8. Parrish, B.; Emrick, T. Soluble Camptothecin Derivatives Prepared by Click Cycloaddition Chemistry on Functional Aliphatic Polyesters. Bioconjugate Chem. 2007, 18, 263-267. [CrossRef]

9. Pokhodylo, N.; Shyyka, O.; Matiychuk, V. Synthesis and Anticancer Activity Evaluation of New 1,2,3-Triazole-4-Carboxamide Derivatives. Med. Chem Res. 2014, 23, 2426-2438. [CrossRef]

10. Wilhelm, E.A.; Machado, N.C.; Pedroso, A.B.; Goldani, B.S.; Seus, N.; Moura, S.; Savegnago, L.; Jacob, R.G.; Alves, D. Organocatalytic Synthesis and Evaluation of 7-Chloroquinoline-1,2,3-Triazoyl Carboxamides as Potential Antinociceptive, Anti-Inflammatory and Anticonvulsant Agent. RSC Adv. 2014, 4, 41437-41445. [CrossRef]

11. Chavan, S.R.; Gavale, K.S.; Khan, A.; Joshi, R.; Kumbhar, N.; Chakravarty, D.; Dhavale, D.D. Iminosugars Spiro-Linked with Morpholine-Fused 1,2,3-Triazole: Synthesis, Conformational Analysis, Glycosidase Inhibitory Activity, Antifungal Assay, and Docking Studies. ACS Omega 2017, 2, 7203-7218. [CrossRef]

12. Hein, C.D.; Liu, X.-M.; Wang, D. Click Chemistry, a Powerful Tool for Pharmaceutical Sciences. Pharm Res. 2008, 25, 2216-2230. [CrossRef] [PubMed]

13. Tron, G.C.; Pirali, T.; Billington, R.A.; Canonico, P.L.; Sorba, G.; Genazzani, A.A. Click Chemistry Reactions in Medicinal Chemistry: Applications of the 1,3-Dipolar Cycloaddition between Azides and Alkynes. Med. Res. Rev. 2008, 28, 278-308. [CrossRef] [PubMed]

14. Angell, Y.L.; Burgess, K. Peptidomimetics via Copper-Catalyzed Azide-Alkyne Cycloadditions. Chem. Soc. Rev. 2007, 36, 1674. [CrossRef] [PubMed]

15. Oueis, E.; Jaspars, M.; Westwood, N.J.; Naismith, J.H. Enzymatic Macrocyclization of 1,2,3-Triazole Peptide Mimetics. Angew. Chem. Int. Ed. 2016, 55, 5842-5845. [CrossRef] [PubMed]

16. Huisgen, R. 1,3-Dipolar Cycloadditions. Past and Future. Angew. Chem. Int. Ed. Engl. 1963, 2, 565-598. [CrossRef]

17. Rostovtsev, V.V.; Green, L.G.; Fokin, V.V.; Sharpless, K.B. A Stepwise Huisgen Cycloaddition Process: Copper(I)-Catalyzed Regioselective "Ligation" of Azides and Terminal Alkynes. Angew. Chem. Int. Ed. 2002, 41, 2596-2599. [CrossRef] 
18. Tornøe, C.W.; Christensen, C.; Meldal, M. Peptidotriazoles on Solid Phase: [1,2,3]-Triazoles by Regiospecific Copper(I)-Catalyzed 1,3-Dipolar Cycloadditions of Terminal Alkynes to Azides. J. Org. Chem. 2002, 67, 3057-3064. [CrossRef]

19. Krasiński, A.; Radić, Z.; Manetsch, R.; Raushel, J.; Taylor, P.; Sharpless, K.B.; Kolb, H.C. In Situ Selection of Lead Compounds by Click Chemistry: Target-Guided Optimization of Acetylcholinesterase Inhibitors. J. Am. Chem. Soc. 2005, 127, 6686-6692. [CrossRef]

20. Lee, L.V.; Mitchell, M.L.; Huang, S.-J.; Fokin, V.V.; Sharpless, K.B.; Wong, C.-H. A Potent and Highly Selective Inhibitor of Human

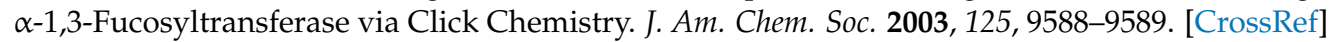

21. Hein, J.E.; Tripp, J.C.; Krasnova, L.B.; Sharpless, K.B.; Fokin, V.V. Copper(I)-Catalyzed Cycloaddition of Organic Azides and 1-Iodoalkynes. Angew. Chem. Int. Ed. 2009, 48, 8018-8021. [CrossRef]

22. Zhang, L.; Chen, X.; Xue, P.; Sun, H.H.Y.; Williams, I.D.; Sharpless, K.B.; Fokin, V.V.; Jia, G. Ruthenium-Catalyzed Cycloaddition of Alkynes and Organic Azides. J. Am. Chem. Soc. 2005, 127, 15998-15999. [CrossRef] [PubMed]

23. Boren, B.C.; Narayan, S.; Rasmussen, L.K.; Zhang, L.; Zhao, H.; Lin, Z.; Jia, G.; Fokin, V.V. Ruthenium-Catalyzed Azide-Alkyne Cycloaddition: Scope and Mechanism. J. Am. Chem. Soc. 2008, 130, 8923-8930. [CrossRef] [PubMed]

24. McNulty, J.; Keskar, K.; Vemula, R. The First Well-Defined Silver(I)-Complex-Catalyzed Cycloaddition of Azides onto Terminal Alkynes at Room Temperature. Chem. Eur. J. 2011, 17, 14727-14730. [CrossRef] [PubMed]

25. McNulty, J.; Keskar, K. Discovery of a Robust and Efficient Homogeneous Silver(I) Catalyst for the Cycloaddition of Azides onto Terminal Alkynes. Eur. J. Org. Chem. 2012, 2012, 5462-5470. [CrossRef]

26. Ding, S.; Jia, G.; Sun, J. Iridium-Catalyzed Intermolecular Azide-Alkyne Cycloaddition of Internal Thioalkynes under Mild Conditions. Angew. Chem. Int. Ed. 2014, 53, 1877-1880. [CrossRef]

27. Jalani, H.; Karagöz, A.; Tsogoeva, S. Synthesis of Substituted 1,2,3-Triazoles via Metal-Free Click Cycloaddition Reactions and Alternative Cyclization Methods. Synthesis 2016, 49, 29-41. [CrossRef]

28. Lima, C.G.S.; Ali, A.; van Berkel, S.S.; Westermann, B.; Paixão, M.W. Emerging Approaches for the Synthesis of Triazoles: Beyond Metal-Catalyzed and Strain-Promoted Azide-Alkyne Cycloaddition. Chem. Commun. 2015, 51, 10784-10796. [CrossRef] [PubMed]

29. Ramasastry, S.S.V. Enamine/Enolate-Mediated Organocatalytic Azide-Carbonyl [3+2] Cycloaddition Reactions for the Synthesis of Densely Functionalized 1,2,3-Triazoles. Angew. Chem. Int. Ed. 2014, 53, 14310-14312. [CrossRef] [PubMed]

30. John, J.; Thomas, J.; Dehaen, W. Organocatalytic Routes toward Substituted 1,2,3-Triazoles. Chem. Commun. 2015, 51, 10797-10806. [CrossRef]

31. Ramachary, D.B.; Ramakumar, K.; Narayana, V.V. Amino Acid-Catalyzed Cascade [3+2]-Cycloaddition/Hydrolysis Reactions Based on the Push-Pull Dienamine Platform: Synthesis of Highly Functionalized N H-1,2,3-Triazoles. Chem. Eur. J. 2008, 14, 9143-9147. [CrossRef]

32. Danence, L.J.T.; Gao, Y.; Li, M.; Huang, Y.; Wang, J. Organocatalytic Enamide-Azide Cycloaddition Reactions: Regiospecific Synthesis of 1,4,5-Trisubstituted-1,2,3-Triazoles. Chem. Eur. J. 2011, 17, 3584-3587. [CrossRef] [PubMed]

33. Belkheira, M.; El Abed, D.; Pons, J.-M.; Bressy, C. Organocatalytic Synthesis of 1,2,3-Triazoles from Unactivated Ketones and Arylazides. Chem. Eur. J. 2011, 17, 12917-12921. [CrossRef] [PubMed]

34. Sangwan, R.; Javed; Dubey, A.; Mandal, P.K. Organocatalytic [3+2] Cycloadditions: Toward Facile Synthesis of Sulfonyl-1,2,3Triazolyl and Fully Substituted 1,2,3-Triazolyl Glycoconjugates. ChemistrySelect 2017, 2, 4733-4743. [CrossRef]

35. Nogueira, C.W.; Rocha, J.B.T. Organoselenium and organotellurium compounds: Toxicology and pharmacology. In PATAI'S Chemistry of Functional Groups; Rappoport, Z., Ed.; John Wiley \& Sons, Ltd.: Chichester, UK, 2011; ISBN 9780470682531.

36. Alberto, E.E.; Braga, A.L. Selenium and Tellurium Chemistry: From Small Molecules to Biomolecules and Materials; Derek, W.J., Risto, L., Eds.; Springer: Berlin/Heidelberg, Germany, 2011; ISBN 978-3-642-20699-3.

37. Iwaoka, M. Antioxidant Organoselenium Molecules. In Organoselenium Chemistry: Between Synthesis and Biochemistry; Santi, C., Ed.; Bentham Science, e-book: Sharjah, United Arab Emirates, 2014; ISBN 978-1-60805-838-9.

38. Menezes, P.H.; Zeni, G. Vinyl Selenides. In PATAI'S Chemistry of Functional Groups; Rappoport, Z., Ed.; John Wiley \& Sons, Ltd.: Chichester, UK, 2011; ISBN 9780470682531.

39. Ursini, F.; Bindoli, A. The Role of Selenium Peroxidases in the Protection against Oxidative Damage of Membranes. Chem. Phys. Lipids 1987, 44, 255-276. [CrossRef]

40. Stazi, A.V.; Trinti, B. Selenium deficiency in celiac disease: Risk of autoimmune thyroid diseases. Minerva Med. 2008, 99, 643-653. [PubMed]

41. Petronilho, F.; Michels, M.; Danielski, L.G.; Goldim, M.P.; Florentino, D.; Vieira, A.; Mendonça, M.G.; Tournier, M.; Piacentini, B.; Giustina, A.D.; et al. Diphenyl Diselenide Attenuates Oxidative Stress and Inflammatory Parameters in Ulcerative Colitis: A Comparison with Ebselen. Pathol. Res. Pract. 2016, 212, 755-760. [CrossRef] [PubMed]

42. Rosa, S.G.; Quines, C.B.; Stangherlin, E.C.; Nogueira, C.W. Diphenyl Diselenide Ameliorates Monosodium Glutamate Induced Anxiety-like Behavior in Rats by Modulating Hippocampal BDNF-Akt Pathway and Uptake of GABA and Serotonin Neurotransmitters. Physiol. Behav. 2016, 155, 1-8. [CrossRef] [PubMed]

43. Oliveira, C.E.S.; Sari, M.H.M.; Zborowski, V.A.; Araujo, P.C.O.; Nogueira, C.W.; Zeni, G. P,P'-Methoxyl-Diphenyl Diselenide Elicits an Antidepressant-like Effect in Mice without Discontinuation Anxiety Phenotype. Pharmacol. Biochem. Behav. 2017, 154, 31-38. [CrossRef] [PubMed] 
44. Reis, A.S.; Pinz, M.; Duarte, L.F.B.; Roehrs, J.A.; Alves, D.; Luchese, C.; Wilhelm, E.A. 4-Phenylselenyl-7-Chloroquinoline, a Novel Multitarget Compound with Anxiolytic Activity: Contribution of the Glutamatergic System. J. Psychiatr. Res. 2017, 84, 191-199. [CrossRef]

45. Salgueiro, W.G.; Goldani, B.S.; Peres, T.V.; Miranda-Vizuete, A.; Aschner, M.; da Rocha, J.B.T.; Alves, D.; Ávila, D.S. Insights into the Differential Toxicological and Antioxidant Effects of 4-Phenylchalcogenil-7-Chloroquinolines in Caenorhabditis Elegans. Free Rad. Biol. Med. 2017, 110, 133-141. [CrossRef]

46. Lopes, E.F.; Penteado, F.; Thurow, S.; Pinz, M.; Reis, A.S.; Wilhelm, E.A.; Luchese, C.; Barcellos, T.; Dalberto, B.; Alves, D.; et al. Synthesis of Isoxazolines by the Electrophilic Chalcogenation of $\beta, \gamma$-Unsaturated Oximes: Fishing Novel Anti-Inflammatory Agents. J. Org. Chem. 2019, 84, 12452-12462. [CrossRef]

47. Wirth, T. (Ed.) Organoselenium Chemistry: Synthesis and Reactions; Wiley-VCH-Verl: Weinheim, Germany, 2012; ISBN 9783527641956.

48. Perin, G.; Alves, D.; Jacob, R.G.; Barcellos, A.M.; Soares, L.K.; Lenardão, E.J. Synthesis of Organochalcogen Compounds Using Non-Conventional Reaction Media. ChemistrySelect 2016, 1, 205-258. [CrossRef]

49. Lenardão, E.J.; Santi, C.; Sancineto, L. New Frontiers in Organoselenium Compounds; Springer International Publishing: Cham, Switzerland, 2018; ISBN 9783319924045.

50. Alves, D.; Goldani, B.; Lenardão, E.J.; Perin, G.; Schumacher, R.F.; Paixão, M.W. Copper Catalysis and Organocatalysis Showing the Way: Synthesis of Selenium-Containing Highly Functionalized 1,2,3-Triazoles. Chem. Rec. 2018, 18, 527-542. [CrossRef] [PubMed]

51. Cruz, E.H.G.; Silvers, M.A.; Jardim, G.A.M.; Resende, J.M.; Cavalcanti, B.C.; Bomfim, I.S.; Pessoa, C.; de Simone, C.A.; Bottesele, G.V.; Braga, A.L.; et al. Synthesis and Antitumor Activity of Selenium-Containing Quinone-Based Triazoles Possessing two Redox Centres, and their Mechanistic Insights. Eur. J. Med. Chem. 2016, 122, 1-16. [CrossRef]

52. Jardim, G.A.M.; Lima, D.J.B.; Valença, W.O.; Lima, D.J.B.; Cavalcanti, B.C.; Pessoa, C.; Rafique, J.; Braga, A.L.; Jacob, C.; da Silva Júnior, E.N.; et al. Synthesis of Selenium-Quinone Hybrid Compounds with Potential Antitumor Activity via Rh-Catalyzed C-H Bond Activation and Click Reactions. Molecules 2018, 23, 83. [CrossRef]

53. Cui, F.; Chen, J.; Mo, Z.; Su, S.; Chen, Y.; Ma, X.; Tang, H.; Wang, H.; Pan, Y.; Xu, Y. Copper-Catalyzed Decarboxylative/Click Cascade Reaction: Regioselective Assembly of 5-Selenotriazole Anticancer Agents. Org. Lett. 2018, 20, 925-929. [CrossRef] [PubMed]

54. Wang, W.; Peng, X.; Wei, F.; Tung, C.-H.; Xu, Z. Copper(I)-Catalyzed Interrupted Click Reaction: Synthesis of Diverse 5-HeteroFunctionalized Triazoles. Angew. Chem. Int. Ed. 2016, 55, 649-653. [CrossRef] [PubMed]

55. Stefani, H.A.; Leal, D.M.; Manarin, F. 4-Organochalcogenoyl-1H-1,2,3-Triazoles: Synthesis and Functionalization by a NickelCatalyzed Negishi Cross-Coupling Reaction. Tetrahedron Lett. 2012, 53, 6495-6499. [CrossRef]

56. Saraiva, M.; Seus, N.; de Souza, D.; Rodrigues, O.; Paixão, M.; Jacob, R.; Lenardão, E.; Perin, G.; Alves, D. Synthesis of [(Arylselanyl)Alkyl]-1,2,3-Triazoles by Copper-Catalyzed 1,3-Dipolar Cycloaddition of (Arylselanyl)Alkynes with Benzyl Azides. Synthesis 2012, 44, 1997-2004. [CrossRef]

57. Braga, A.L.; Reckziegel, A.; Silveira, C.C.; Comasseto, J.V. Vicinal Difunctionalization of Alkynyl Selenides with Lithium Butylcyano Cuprate and Electrophiles. Synth. Commun. 1994, 24, 1165-1170. [CrossRef]

58. Lopes, E.F.; Dalberto, B.T.; Perin, G.; Alves, D.; Barcellos, T.; Lenardão, E.J. Synthesis of Terminal Ethynyl Aryl Selenides and Sulfides Based on the Retro-Favorskii Reaction of Hydroxypropargyl Precursors. Chem. Eur. J. 2017, 23, 13760-13765. [CrossRef] [PubMed]

59. Ivasiv, V.; Albertini, C.; Gonçalves, A.E.; Rossi, M.; Bolognesi, M.L. Molecular Hybridization as a Tool for Designing Multitarget Drug Candidates for Complex Diseases. Curr. Top. Med. Chem. 2019, 19, 1694-1711. [CrossRef] [PubMed]

60. Viegas-Junior, C.; Barreiro, E.J.; Fraga, C.A.M. Molecular Hybridization: A Useful Tool in the Design of New Drug Prototypes. Curr. Med. Chem. 2007, 14, 1829-1852. [CrossRef] [PubMed]

61. Li, L.-J.; Zhang, Y.-Q.; Zhang, Y.; Zhu, A.-L.; Zhang, G.-S. Synthesis of 5-Functionalized-1,2,3-Triazoles via a One-Pot Aerobic Oxidative Coupling Reaction of Alkynes and Azides. Chin. Chem. Lett. 2014, 25, 1161-1164. [CrossRef] 